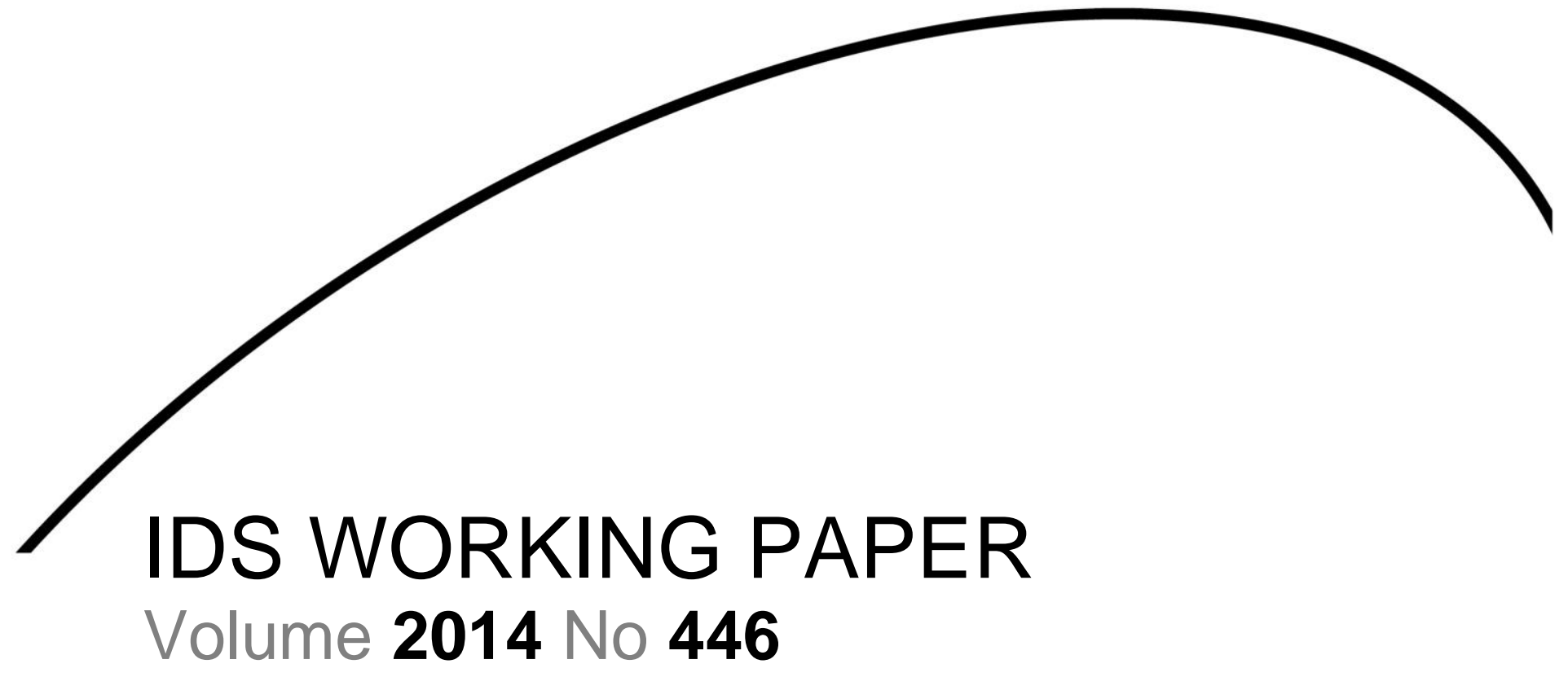

Political Economy of Climate Compatible Development: Artisanal Fisheries and Climate Change in Ghana

Thomas Tanner, Adelina Mensah, Elaine T. Lawson, Chris Gordon, Rachel Godfrey-Wood and Terry Cannon

June 2014 
This document is an output from a project funded by the UK Department for International Development (DFID) and the Netherlands Directorate-General for International Cooperation (DGIS) for the benefit of developing countries. However, the views expressed and information contained in it are not necessarily those of or endorsed by DFID or DGIS, who can accept no responsibility for such views or information or for any reliance placed on them.

This publication has been prepared for general guidance on matters of interest only, and does not constitute professional advice. You should not act upon the information contained in this publication without obtaining specific professional advice. No representation or warranty (express or implied) is given as to the accuracy or completeness of the information contained in this publication, and, to the extent permitted by law, the entities managing the delivery of the Climate and Development Knowledge Network* and [Institute for Development Studies] do not accept or assume any liability, responsibility or duty of care for any consequences of you or anyone else acting, or refraining to act, in reliance on the information contained in this publication or for any decision based on it.

(C) 2012, All rights reserved

Political Economy of Climate Compatible Development: Artisanal Fisheries and Climate Change in Ghana Thomas Tanner, Adelina Mensah, Elaine T. Lawson, Chris Gordon, Rachel Godfrey-Wood and Terry Cannon IDS Working Paper 446

First published by the Institute of Development Studies in June 2014

(C) Institute of Development Studies 2014

ISSN: 2040-0209 ISBN: 978-1-78118-185-0

A catalogue record for this publication is available from the British Library.

All rights reserved. Reproduction, copy, transmission, or translation of any part of this publication may be made only under the following conditions:

- with the prior permission of the publisher; or

- with a licence from the Copyright Licensing Agency Ltd., 90 Tottenham Court Road, London

W1P 9HE, UK,

or from another national licensing agency; or

- under the terms set out below.

This publication is copyright, but may be reproduced by any method without fee for teaching or nonprofit purposes, but not for resale. Formal permission is required for all such uses, but normally will be granted immediately. For copying in any other circumstances, or for re-use in other publications, or for translation or adaptation, prior written permission must be obtained from the publisher and a fee may be payable.

Available from:

Central Communications, Institute of Development Studies, Brighton BN1 9RE, UK

Tel: +44 (0) 1273915637 Fax: +44 (0) 1273621202

E-mail: bookshop@ids.ac.uk

Web: www.ids.ac.uk/publications

IDS is a charitable company limited by guarantee and registered in England (No. 877338) 


\title{
Political Economy of Climate Compatible Development: Artisanal Fisheries and Climate Change in Ghana
}

\author{
Thomas Tanner, Adelina Mensah, Elaine T. Lawson, Chris Gordon, Rachel \\ Godfrey-Wood and Terry Cannon
}

\section{Summary}

Interest in prospects for policy processes that contribute to development, climate change adaptation and mitigation, known as 'climate compatible development', has been growing in response to increasing awareness of the impacts of climate change. This paper provides insight into the complex political economy of climate compatible development in Ghana's artisanal fisheries, a sector that has received comparatively little attention in climate change literature and policy processes. It focuses on two contentious policy areas where there is potential for climate compatible development, namely the subsidized premix fuel provided to artisanal fishermen, and mangrove protection. Regarding the premix subsidy, while there is theoretical scope for a 'triple win' outcome by removing the subsidy to reduce incentives to unsustainable fishing and supporting alternative policies, in practice this is highly problematic. Artisanal fishermen strongly oppose removing the subsidy on the grounds that it would damage their livelihoods, and do not have the confidence that they would be appropriately compensated for any hypothetical reform. Moreover, it is argued that removing it could have negative unintended consequences if fishermen are forced into alternative livelihoods that are themselves unsustainable. There is, however, a need to make considerable improvements to the distribution of the premix fuel so that it reaches the intended beneficiaries and is not siphoned off for contraband. Meanwhile, although improved mangrove protection could have significant 'triple-win' benefits, this area suffers from a lack of funding and administrative coordination across ministries and agencies, leading it to be neglected. The case studies reveal, therefore, that the major constraint to climate compatible development is institutional failing, rather than a lack of policies per se. The paper emphasizes the need to conceptualize climate compatible development as a process which is dynamic across space and time, such that potential for triple win outcomes is fluctuate to vary according to changing circumstances. It is necessary to recognize, furthermore, that pressures from a number of actors, including those at the grass roots, may demand short term improvements to current problems rather than aspiring to triple win outcomes in the long term, creating a major challenge for climate compatible development.

Keywords: Climate change; political economy; climate compatible development; fisheries; Ghana.

Thomas Tanner ${ }^{1}$ is Head of Adaptation and Resilience, and a Research Fellow at the Overseas Development Institute (ODI), working on adaptation to the impacts of climate change, including the political economy of climate change and development; organisational change; poverty, vulnerability and climate adaptation; children and disasters; and building resilience in urban contexts. He has 20 years of experience as a researcher, policy maker, practitioner, and negotiator in UN conventions on climate and desertification.

Adelina Mensah is a Research Fellow at the Institute for Environment and Sanitation Studies, University of Ghana. Her main area of research is on the varying complexities of inland and coastal aquatic systems, including inter-linkages with socio-economic drivers and 
sustainable management. Other areas include climate change and adaptation, climate change and policy/governance, and environmental change.

Elaine T. Lawson is a Research Fellow at the Institute for Environment and Sanitation Studies, University of Ghana, Legon. Her areas of research include social and cultural impacts of environmental degradation, environmental policy issues, integrated coastal zone management, poverty, rural livelihoods and the environment, vulnerability and adaptation to climate change and environmental education.

Chris Gordon is the Director of the Institute for Environment and Sanitation Studies, University of Ghana and a member of the Earth System Governance Steering Group and the UNEP-PROVIA scientific steering committee. His areas of interest cover coastal zone ecology, water resource management and ecotoxicology as well as ecosystem based climate change adaptation.

Rachel Godfrey-Wood is a PhD student at the Institute of Development Studies. She is using ethnographic methods to research social protection, adaptation to climate change and the lives of older people in rural highland Bolivia. She has worked for several years at IIED and IDS as a research assistant on a broad range of topics including climate change, social protection, and energy access to the poor.

Terry Cannon is Research Fellow at the Institute for Development Studies (IDS) in the UK. $\mathrm{He}$ is currently researching disasters (flood and cyclone) and climate change in South Asia, and local adaptation to climate change in parts of Africa. He is currently co-editing the IFRC World Disasters Report 2014 on the theme "Culture and Risk".

\section{Acknowledgements}

We are very grateful to all those who gave their time to be interviewed for this research, attendees of the Accra Learning Event in February 2014, and facilitation in the field.

Particular thanks go to Jaya Sathaye and Wendy Boakye of the Institute for Environment and Sanitation Studies (IESS) at the University of Ghana for their input into the project. We also thank two referees for the paper, Lars Otto Naess of Institute of Development Studies (IDS) and Neha Rai of International Institute for Environment and Development, UK (IIED). 


\section{Contents}

Summary, keywords, author notes 3

Acknowledgements 4

$\begin{array}{ll}\text { Introduction } & 6\end{array}$

$\begin{array}{lll}1.0 & \text { Climate change and the fisheries sector } & 8\end{array}$

$\begin{array}{lll}2.0 & \text { Inshore artisan fisheries in Ghana } & 8\end{array}$

$\begin{array}{lll}3.0 & \text { Fisheries and the impact of climate change } & 10\end{array}$

4.0 Politics of the marine fisheries sector and related CCD strategies 12

4.1 Fisheries policy and regulatory framework 12

4.2 Premix fuel subsidy 14

$\begin{array}{ll}\text { 4.3 Mangroves } & 15\end{array}$

4.4 National Climate Change Policy $\quad 16$

5.0 Climate Compatible Development Options 16

5.1 Case Study 1: Fuel Subsides and the Politics of Premix 17

5.2 Case Study 2: Mangrove Protection 18

6.0 Reflections on the Political Economy of Climate Compatible Development 20

$\begin{array}{ll}\text { Annex } 1 & 25\end{array}$

$\begin{array}{ll}\text { Annex } 2 & 26\end{array}$

$\begin{array}{lr}\text { References } & 27\end{array}$

\section{Figures}

Figure 1 Climate compatible development 6

Figure 2 Work paper structure: chapters are as numbered in the diagram $\quad 7$

Figure 3 The regulatory framework of fisheries management in Ghana 13

Figure 4 Expanding the potential for 'triple wins' 23

Figure 5 Dynamic triple wins across space and time 24 


\section{Introduction}

Should development be integrated with both adaptation to climate change and reduction of greenhouse gas (GHG) emissions? There is growing acceptance that this is essential for success in each of the three arenas. The challenges involved in linking them has led to rising interest in how to support more integrated approaches for development, adaptation, and mitigation. Integration has been variously termed low carbon climate resilient development, 'triple wins', and climate compatible development (CCD) (see Figure 1).

\section{Figure 1 Climate compatible development}

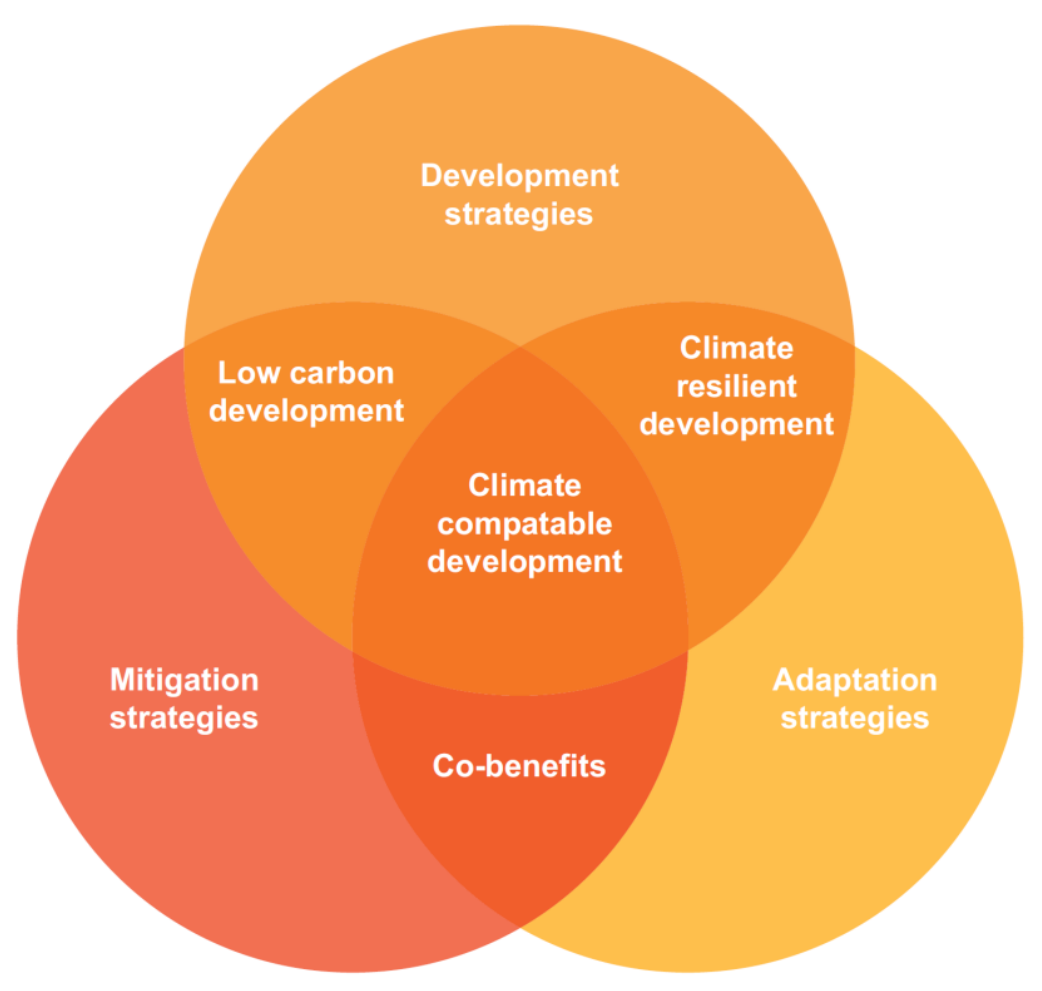

Source: Mitchell and Maxwell (2010) reproduced by kind permission of CDKN.

Ellis et al., (2013) synthesized the wide range of socio-political forces that are driving CCD policies and processes. These include the linking of adaptation processes with wider resilience, growth and poverty reduction; linking mitigation with energy security and natural resource efficiency goals; harnessing new economic opportunities and sources of finance associated with climate change; and strong government leadership. Current challenges to CCD include the costs associated with policy change; opposition from interest groups who might lose out; low awareness and poor information on uncertainties, risks, opportunities and trade-offs; the short-term nature of policy and decision making; short political election cycles; and institutional and technological constraints, including lack of capacity to respond to and implement strategies.

This paper presents results of research that explores these socio-political forces and challenges by understanding the political economy of CCD in relation to the marine fisheries in Ghana. Building on other research approaches to climate change and development (Tanner and Allouche, 2011), our analytical framework for political economy aims to identify: 
a. The policy and actor context underpinning CCD in this sector

b. The power relations, competition, cooperation and conflict between different interest groups driving policies and access to resources

c. The distributional consequences of different actions on these interest groups, and possible tradeoffs between groups and different objectives.

The research provides insight into the complex political economy in Ghana's artisanal fisheries, a sector that has received comparatively little attention with regards to climate change linkages. In doing so, we aim to help other projects and wider initiatives for tackling climate change to locate their work within a political economy context, and target efforts in politically smart ways. The structure for this working paper is illustrated in Figure 2. In describing the rationale, it outlines the context for the artisanal fisheries sector and challenges to its sustainability and relations with climate change. It then analyses the politics of climate change policy formulation, including its relationship with the fisheries sector.

Two case studies analyse potential strategies for climate compatible development: reductions in fuel subsidy for small-scale fishing boats and enhanced mangrove protection. These were chosen to provide a more concrete way to analyse the political economy issues. Fuel subsidy is provided by the government to fisherman to improve their income levels. It is used in engines for small boats in the artisan fisheries. It is a highly politicised aspect of relations of artisan fishers with the government and a source of controversy that is under pressure to be reduced. It is a source of carbon emissions, and so allows an assessment of how support to livelihoods and poverty reduction can conflict with mitigation. Mangrove protection is contentious because of conflicts over different uses of the coastline, the potential for carbon credits, and the ecological significance of the mangroves as spawning areas for fish. The two case studies enable us to analyse the three aspects of the political economy analysis, using the framing of context, competition and consequences across different actors.

The research was carried out by a team from the Institute for Environment and Sanitation Studies at the University of Ghana and the Institute of Development Studies, UK in 2013-14. The team employed a combination of documentary analysis, formal and informal interviews with key stakeholders and a participatory Learning Event in February 2014, using stakeholder mapping and visualisation techniques to deepen analysis of the two case study CCD issues. See Annex 1 and 2 for details of interviewees and participants.

Figure 2 Work paper structure: chapters are as numbered in the diagram

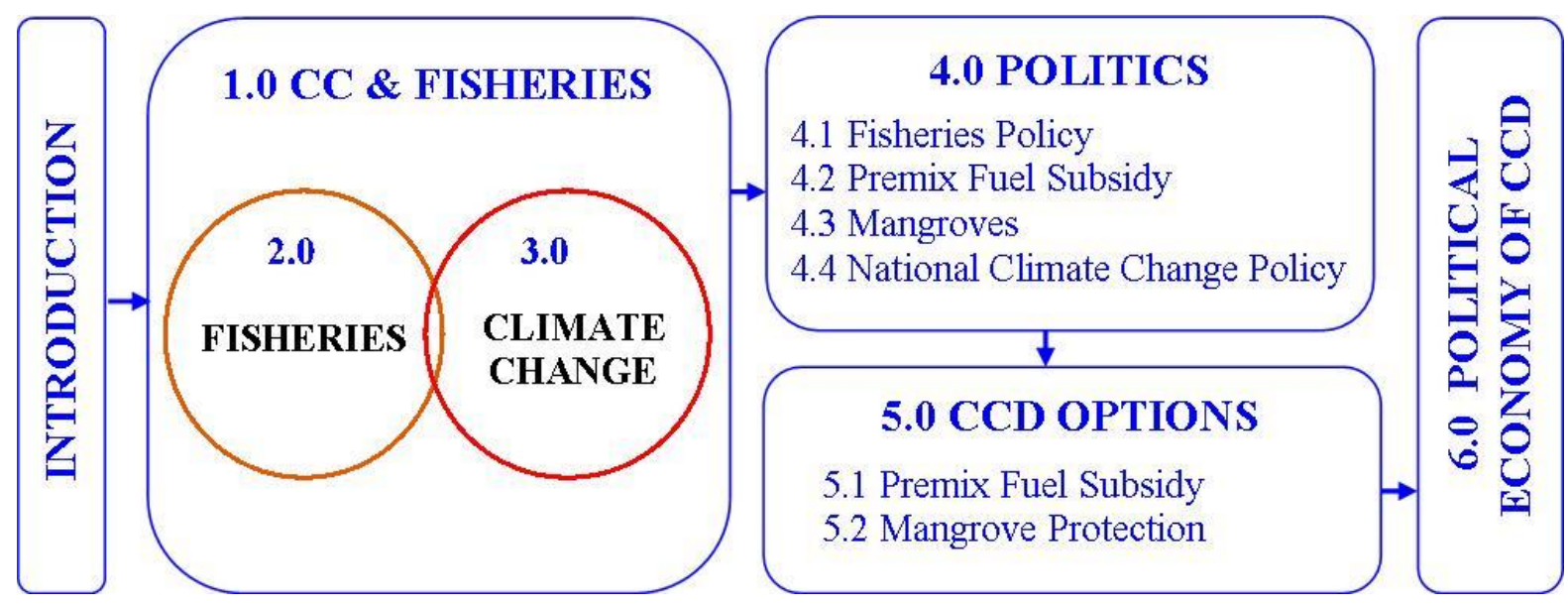

Source: authors' own. 


\subsection{Climate change and the fisheries sector}

Ghana provides an excellent example of the additional challenges that climate change and variability place on development. It has made significant economic progress in recent decades and achieved middle income country status. Like all other countries, this progress is accompanied by rising greenhouse gas (GHG) emissions, and Ghana has moved from being a net carbon sink to a net emitter. The sink decline is due to deforestation. Net GHG emissions rose from an estimated minus 16.8 million tonnes of $\mathrm{CO}_{2}$ equivalent in 1990 , to 23.8 MT in 2006, with $40 \%$ of the emissions from energy, $24 \%$ from agriculture and $25 \%$ from land use, land use change and forestry (MEST, 2011).

Fisheries play a key role in livelihoods for people along the $550 \mathrm{~km}$ coastline. The impacts of and responses to climate change have significant implications on the fisheries sector and the lives of poor people (Allison et al., 2005). The marine fisheries are expected to be adversely affected by climate change. It also contributes to the country's greenhouse gas emissions, mainly by burning engine fuel (MEST, 2011). Ghana's response to climate change, however, presents opportunities for the fisheries sector to improve its efficiency, sustainability and support for climate compatible wealth creation. Dealing with climate change impacts on fisheries is linked to wider management challenges in the sector. These include weak monitoring, poor enforcement, uncontrolled growth of trawler-based commercial fishing (and their emissions), a rise in illegal, unreported and unregulated artisanal (IUU) fishing practices and declining fish stocks among key commercial species.

Climate change-related initiatives in Ghana are increasing, and the government is committed to mainstreaming climate change responses into multi-scale and multi-sector planning and policy processes (MEST, 2011). At the same time, Ghana is supporting a rapid expansion of offshore oil and gas exploration and production. In addition to potential benefits from revenues, employment and energy security, the oil industry also has implications for increasing global emissions and could potentially harm coastal livelihoods, including fisheries (through oil spills and other pollution related to the industry).

\subsection{Artisanal fisheries in Ghana}

Fisheries, both marine and inland (on rivers, lakes and lagoons) play a vital role in livelihoods and are crucial for nutrition in Ghana (most of the catch is consumed within the country). The fisheries sector accounts for 1.4 percent of Ghana's Gross Domestic Product (GDP) (Ghana Statistical Service, 2014) and employs at least 2 million people, including 135,000 fishers in the marine sector (Finegold et al., 2010). Marine fisheries provide $75 \%$ of Ghana's total annual catch (Agrer, 2011) of which the majority is from inshore artisanal fishing. The remaining $25 \%$ is from lakes and rivers, which we are not concerned with in this study. Processing, distribution and local trading are often done by women. In recent years, ten landing points have been improved with ice-making and freezer storage. However, Ghana's marine fisheries are under many pressures from over-exploitation, IUU fishing by foreign fleets, habitat destruction (including mangroves), climate change, and coastal urban and industrial growth (including the emerging oil and gas sector).

There are three types of fishing fleets: (i) the artisanal canoes (mainly but not all motorized), (ii) semi-industrial boats (wooden-planked vessels) and (iii) industrial vessels (large-scale trawlers and tuna boats). Of the three, the small scale artisanal fleet is the largest, contributing 60 to 70 percent of the total annual marine fish output of small pelagic fish species. This consists of over 12,000 wooden dugout canoes (FASDP, 2009 in CRC, 2010) 
that range in size from small, paddle powered canoes, to boats up to $16 \mathrm{~m}$ in length powered by outboard motors. The canoes are usually Ghanaian-owned with crews of up to 20 that are almost exclusively men. Approximately $55 \%$ of canoes are motorised, with large canoes usually powered by $40 \mathrm{hp}$ outboard motors and small canoes often carrying 8hp motors (Finegold et al., 2010). The number of canoes has increased in recent years due to the reintroduction of the subsidised premix fuel programme (CRC, 2010).

The canoe fishers use purse seines, various entangling and gill nets, encircling nets, long lines and hand lines. They mainly harvest small seasonal pelagic fish, whose numbers peak as a result of an offshore upwelling of water that brings nutrients to fuel their food chain during December to February and July to September; making these the key periods for fishing (FAO, 2010). Some artisan fishers fish all year round, however, many may find alternative employment through subsistence farming, small trade, lagoon fishing, sand mining or stone quarrying (Mensah and Antwi, 2002).

With approximately 350 vessels operating from seven landing sites, the semi-industrial fleet is the second largest. These diesel-fuelled, wooden plank boats are either Ghanaian or joint ventures between Ghanaian and foreign owners. They catch pelagics in the upwelling season, with some of the larger vessels switching to trawling for demersal species such as grouper, and use traps for lobster during the off-season. The time that canoes and semiindustrial boats can stay at sea is dependent on the amount of ice and fuel that they have available. Purse seiners tend to fish overnight. Trawlers and canoes using drift gillnets or hook and line may stay at sea for several days (Bennett, 2002).

Lights are often used illegally by canoes and semi-industrial vessels to attract shoals of small pelagic fish into shallower waters (Finegold et al., 2010). Other illegal techniques such as the use of small mesh sizes, fish aggregating devices (FAD), poisons, explosives, pair trawling and illegal trawling close to the shore are all having excessive pressure (Finegold et al., 2010). Some of these activities are done outside what is regarded as the peak fishing season.

The large, steel-hulled industrial trawler fleet are supposed by law to operate in waters more than $30 \mathrm{~m}$ deep. There are about 80 vessels that operate from ports at Tema and Takoradi, which have berthing facilities. The industrial fleets have freezing facilities on board, enabling them to remain at sea for longer periods. There is also a tuna fleet of 35 to 40 vessels that operate much further afield, often staying at sea for several months and sending fish ashore on carrier boats (CRC, 2010; Finegold et al., 2010; Bennett, 2002). All of the industrial ships are supposed to be either Ghanaian or Ghana-foreign joint ventures, but there is a significant problem with illegal, unreported and unregulated (IUU) foreign vessels encroaching West African waters.

Ghana's marine fisheries output has decreased significantly in recent decades. Between 1996 and 2011, catches declined 66\% from 252,112 to 84,980 metric tons (CRC, 2013). This is despite laws and regulations intended to improve output but reduce overfishing. To conform to the World Bank and IMF structural readjustment programmes of the 1980s and 90s, much of Ghana's governance structure, including fisheries management, was decentralised. The current regulatory framework, drawn up within the Fisheries Act 2002, is based on this decentralised structure in which central government is responsible for policy formation, monitoring and evaluation, while implementation is under the local District Assemblies and Community Based Fisheries Management Committees (CBFMCs). There are problems with the implementation of this decentralised system, especially the distribution of insufficient funds from central to local government (Mohan, 1996). In practice, responsibility for fisheries management lies predominantly with central government bodies (CRC, 2010; Mutimukuru-Maravanyika et al., 2013). 
There are also a number of key multilateral and bilateral donor agencies involved in Ghana's fisheries. The World Bank is supporting Ghana as part of the West Africa Regional Fisheries Programme, and has invested \$54 million

to support the sustainable management of Ghana's fish and aquatic resources by:

(i) strengthening the country's capacity to sustainably govern and manage the fisheries;

(ii) reducing illegal fishing; (iii) increasing the value and profitability generated by the

fish resources and the proportion of that value captured by the country; and (iv) developing aquaculture. ${ }^{2}$

This funding includes a $\$ 3.5$ million grant from the Global Environmental Facility (GEF). Department for International Development (DFID) is providing support for the Sustainable Fisheries Livelihood Development Programme, while aid from Spain's AECID (Agencia Española de Cooperación Internacional para el Desarrollo) is providing investment in cold stores and refrigerated ships (Finegold, 2010). USAID is investing in the Integrated Coastal and Fisheries Governance Initiative.

\subsection{Fisheries and the impact of climate change}

The decline in marine fisheries means that coastal fishing communities are having much lower harvests for the small pelagic species that are critical for their livelihoods (CRC, 2013). Poor governance and open access without controls on fishing effort has led to a boom in the numbers of both artisanal and semi-industrial fishing vessels, causing overfishing. Overall, the regulations of the marine fisheries sector attempt to control unsustainable exploitation through: (i) prescribed mesh sizes (ii) elimination of bad fishing practices, and (iii) reduced industrial vessel fishing through licensing schemes and set fishing zones.

The canoe-based fishers have free access to the resources, except for payments of annual fees to the chief fisherman and traditional regulations of weekly non-fishing days or bans on fishing activities prior to and during annual festivals. Between artisanal fishermen, conflict resolution is typically the remit of chief fishermen who are appointed traditional advisors for the fishing community and assisted by a council of elders. Different ethnic groups tend to use a variety of fishing techniques, and this reduces the potential for overlap and conflict. But conflicts do occur between indigenous and migrant fishers, usually over the purchase of premix fuel, fish pricing, non-payment of fish levies, etc. Migrant fishermen are supposed to report to the chief fisherman of the area and abide by local byelaws.

The three fleets interact through their competition for the fish, whose stocks are affected by overfishing. This in turn affects the behaviour of artisan fishers in trying to maintain their catches, by themselves overfishing. Industrial and semi-industrial vessels may come into contact with artisan fishermen. This is either because of their illegal incursion into the Inshore Exclusive Zone (IEZ) that is reserved for artisanal fisheries (which appears to be increasing), or because artisan fishers are going further out to sea. In some instances, artisan fishers may buy 'trash' fish (non-targeted by-catch of little or no market value to the trawler companies) from the industrial trawlers (Nunoo et al, 2009). The Monitoring, Control and Surveillance (MCS) Division of the Fisheries Commission, in collaboration with the Ghana Navy, conduct sea patrols to control industrial fishing vessels from fishing in IEZ. In such cases, culprits are prosecuted by more formal methods, including settlements in court. More recently, in 2011, a special Marine Police Unit (MPU) was re-established to handle criminal 
activities and illegal fishing practices at sea. National plans are also in place to review national legislatives and develop a national plan of action against IUU. This is partly a result of Ghana being confronted (in March 2013) over its failure to comply with EU regulations in controlling IUU fisheries, which led to a ban on tuna exports to the EU.

The fishing industry is being affected by the emergence of the oil and gas industry, with large shoals being attracted at night to the lights of the oil installations. Fishermen complain that this has affected their harvest, and that the industry has brought other problems like pollution from spillage, increased occurrences of brown algae (Sargassum) which they claim was not observed prior to oil production, and destruction of fishing gear and canoes from collisions with oil vessels. Restrictions have been enforced on fishing around the safety zones of the floating platforms.

The fisheries are affected by a range of factors apart from climate change, including overfishing, pollution and eutrophication could lead to similar effects, and it may be difficult to ascertain the causes. A crucial climate issue involves factors that affect the upwelling processes off the coast that can strongly affect nutrients and food supplies for fish, so that fish stocks along the coast of West Africa are affected (Koranteng and McGlade, 2001; Perry and Sumaila, 2007; Wiafe et al., 2008; Katikiro and Macusi, 2012). Fluctuations in fish catch are linked to changes in upwelling, rainfall, recruitment and migration of fish. Models show that rising sea surface temperatures lead to declines in catch in round Sardinellas, but increased catch of anchovy, while flat Sardinella was most affected by projected precipitation changes (Dontwi et al., 2008).

The impacts of climate change can be direct, including changes to wind and temperature that affect stratification and circulation of water. This affects productivity and abundance of various species (e.g., Cheung et al., 2010). Sea level rise and increased extreme weather events can damage coastal habitats, including mangroves that are important for fish breeding and shelter. Extreme weather can also disrupt fishing patterns and damage landing sites, which affects the livelihoods of coastal communities (Katikiro and Macusi, 2012). Indirectly, climate change can affects the physiology and behaviour of the fish stock, through changes to primary and secondary productivity dynamics or prey-predator interactions. This can lead to a decline in fisheries production and even the disappearance of some species (Barange and Perry, 2009).

Artisan fishers and their communities have had effective coping strategies in response to the natural fluctuations in upwelling dynamics. These include more intensive exploitation of natural resources, diversifying income sources, investing in supportive social networks and seasonal or permanent migration (Allison and Ellis, 2001; Koranteng, 2002; Perry and Sumaila, 2007). These are more suitable for seasonal and inter-annual temporal variability rather than longer (e.g. decadal) periods. They may also not help in situations where the expected rate of climate change is more rapid and the fisheries are already under stress (Lehodey et al., 2006). Projections for West Africa show that climate change may lead to a substantial reduction in marine fish production and fish protein supply by the 2050s (Lam et al., 2012). Ghana is second only to Nigeria in the projected negative impacts of climate change on fish landings. These are estimated as 41.5 per cent drop in annual catch for the low (constant $2000 \mathrm{CO}_{2}$ ) GHG emission scenario, and 55.0 percent drop for high range (SRES A1B) scenario. Hence, there are implications for food security and potential conflicts as a result of increased competition over scarcer resources. 


\subsection{Politics of the marine fisheries sector and related CCD strategies}

The project focused on two particular aspects of the political economy of resource and livelihoods that reflect some of the contradictions between different interest groups, thus making CCD potentially difficult. But, at the same time, they clearly have the potential for policy interventions that could support CCD. These two aspects are

- $\quad$ the subsidised premix fuel used by inshore fishers, and

- the mangrove forests that are simultaneously a resource for livelihoods (timber and building material); an ecosystem that supports fish reproduction, and a potential adaptation for coastal climate change threats.

The following sections summarize the policy context of the related policies (fisheries, premix subsidy, mangrove forests and the national climate change policy), and describe the issues and key interest groups that influence policy and implementation.

\subsection{Fisheries policy and regulatory framework}

The existing regime for the regulation of fisheries is a mixture of customary rules and statutory enactments in line with Article 11 of the 1992 Constitution, which mentions both as sources of law in Ghana.. Most of the regulatory frameworks for marine and inland fisheries are under the Fisheries Act 2002 (Act 625) and Fisheries Regulations 2010 (L.I. 1968). The Act provides broad instructions for the sustainable management of fisheries and outlines the regulatory framework within which fisheries are to be managed. The Fisheries Regulation L.I. (1968) was passed in 2010 to support the Fisheries Act 625. It gives detailed directives for prohibited fishing as well as the licensing of fishing vessels, importation of fish, fishing in foreign waters, markings on fishing gears and many others (Yamoah, 2012). An overview of the regulatory framework as outlined in the Fisheries Act can be seen in Figure 3 and is explained in more detail below, along with elaboration on some of the issues fisheries management faces in practice

Since the first Ministry of Fisheries in 1964, fisheries management has been the responsibility of the Department of Fisheries operated within the Ministry of Food and Agriculture (MOFA). In 2004, the Government of Ghana created the Ministry of Fisheries with a cabinet status to give more attention and direction to the management of the resources. After the creation of the ministry and the Fisheries Act of 2002, fisheries management was the responsibility of the Fisheries Commission with the Directorate of Fisheries as its implementing agency/secretariat. However, in 2009, the Ministry of Fisheries was dissolved and the new fisheries commission formed to work under the Ministry of Foods and Agriculture.

The Fisheries Act 6252002 makes provision for the management of the fisheries resources to include operators and industry players. In addition to the Fisheries Commission, the Act also provides for the establishment of a Fisheries Development Fund and its use; and regulates the management and conservation of fishery resources, including aquaculture and small-scale fishing.

The Fisheries Commission carries out various functions in relation to management and conservation of fisheries resources and includes two representatives from the National Fisheries Association of Ghana, one being artisanal and the other an industrial operator. The 
Ghana Marine Fishing Officers Association also nominates a representative to serve on the Commission.

\section{Figure 3 The regulatory framework of fisheries management in Ghana}

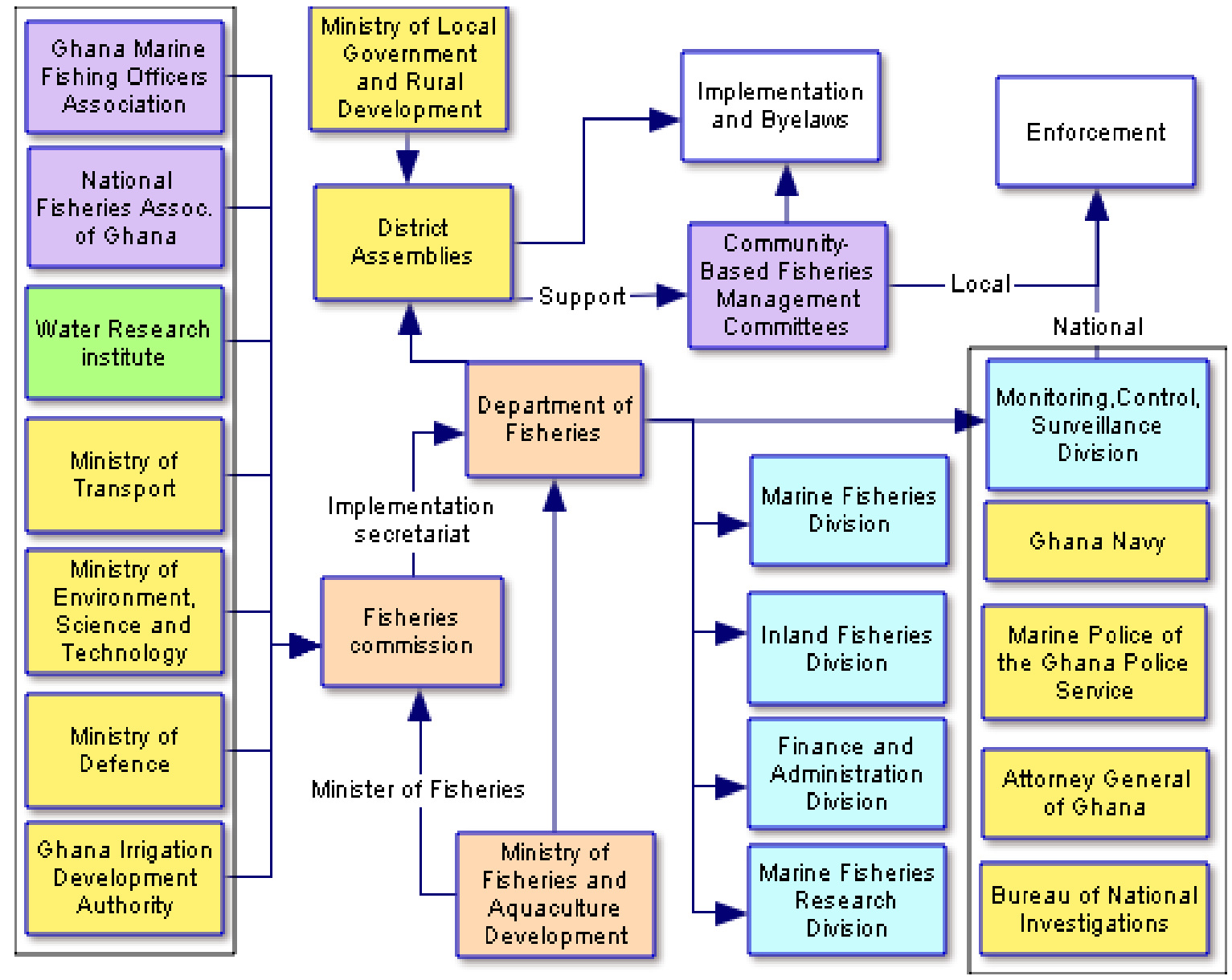

Source: authors' own compiled from information from MoFA (2002), CRC (2010) and FAO (2010).

Since the establishment of the new Ministry for Fisheries and Aquaculture Development in 2013, the sector once again has representation in Cabinet. As established in the Fisheries Act 2002, the Minister responsible for fisheries sets the policy mandate of the Commission. ${ }^{3}$ The directorate is under the leadership of a Director, and has five operational divisions: Marine Fisheries Management Division (MFMD), Inland Fisheries Management (and Aquaculture) Division (IFMD), Marine Fisheries Research Division (MFRD), Monitoring, Control and Surveillance Division (MCSD) and the Finance and Administration.

Some key institutions in the management of the fishery resource can be found under the traditional governance systems. For example, in many fishing communities, fisheries management has traditionally been the responsibility of chief fishermen, and the chief processor or chief fish trader. The chief fisherman is appointed based either on merit or

This has eleven members representing the Ministry of Transport, Ministry of Environment, Science Technology and Innovation, the Ministry of Defence, the Ghana Marine Fishing Officers Association, the Water Research Institute, the Ghana Irrigation Development Authority and the National Fisheries Association of Ghana (two representatives) and a technical expert. 
heritage. Where appointed by merit, nomination may be open to all or limited to a select few depending on the town. Their role includes that of government negotiator, conflict mediator, religious leader and advisor to fishermen. In some cases, they may hold more importance within the village than the village chief.

A number of Fisher Associations also contribute towards the management of fisheries. Two fisher associations are represented within the Fisheries Committee: the Ghana Marine Fishing Officers Association, and the National Fisheries Association of Ghana. Another important fisher association, the Ghana National Canoe Fishermen Council, which is represented on the National Fisheries Association of Ghana, is the main representative body of artisanal fishermen. There are also non-governmental organisations such as the Fisheries Alliance, which is the umbrella organisation for a number of NGOs,

There have been attempts to devolve the management of fisheries resources with the Canoe Fishermen Council, which is the landing area local governing authority serving as the basis. There is the Community Based Fisheries Management Committee concept, which is not fully functional because of resource and legislative capacity. However, the Chief Fisherman exercises full traditional authority within the artisanal sector in the management of the fishery resources. They constitute the core of the Regional and National Canoe Fishermen Council, which has requisite influence in the management of the resources.

\subsection{Premix fuel subsidy}

Most small-scale fishers who use boats powered by engines, use the two-stroke outboard engine that is fuelled by a mix of oil and petrol (referred to as premix). For most of the time since its re-introduction in 1995, premix was heavily subsidised to support fishers in the same way subsidies on fertilizer were given to farmers. This was expected to help artisanal fishermen increase their catch and hence raise their living standards through higher incomes. Although the subsidy helped fishers cope with lower income from declining catches, this encourages fishing with diminishing stocks and is therefore unsustainable and mal-adaptive. Ideally, diversification away from unsustainable fishing practices should be supported. Fossil fuel subsidy reform has already been cited as a potential triple win strategy (Crawford 2012). The International Energy Agency (IEA) has estimated that the phasing out of fossil fuel subsidies for consumption by 2020 could reduce global greenhouse gas emissions by $5 \%$ (IEA 2011). The subsidy has been reduced in 2013 , with a $20 \%$ increase in purchase price, ${ }^{4}$ leading to significant beaching of vessels when fishers can no longer afford to put to sea. ${ }^{5}$

After the official announcement of the premix subsidy in Ghana, its sale and distribution has had various operational structures and committees as a result of different governments in power. This affected how the product was sold to the fishermen (Abane et al., 2013). In 1995, for example, there was a ministerial committee responsible for the distribution and implementation of the subsidy prices, and premix was to be sold only to registered cooperatives. However, service centres were also set up to sell the premix and were made up of political appointees. These service centres took over the functions of the national committee who had the rights to issue licences for the supply of premix to fishermen. The premix was sold at higher prices than the subsidies, with the extra profits going to individuals, and shortages were created.

With the change in the government in 2000 , the structure was changed to a national premix committee, the regional co-ordinating committee on premix and the local premix committee. The local premix committee was responsible for the sale of premix directly to the fishermen.

www.modernghana.com/news/479729/1/energy-ministry-justifies-kerosene-premix-fuel-pri.html http://graphic.com.gh/news/general-news/20240-fishermen-ground-canoes.html 
The fuel is sold to local landing committees at production cost and sold on to fishers with a mark-up, in order to provide funds for local development and administration. Even then, the regional committee was taking unilateral decisions and determining how premix was supplied and in what quantities. According to Abane et al., 2003, there was a proliferation of premix outlets, rising from 127 owned by private individual between 1995 and 1999, to 600 in 2006, and up to 900 in 2012.

The subsidy programme has faced various problems from the beginning, with fuel diversion onto the black market, leaving fishers unable to access premix. Recently, this has been curtailed by dyeing the fuel and putting clear markings on the fuel tankers to prevent reroutes. Despite controversy and difficulties in the management of the premix programme, the policy is extremely important to many fishers, particularly the artisanal fleet. Even though the World Bank and Government of Ghana are still planning to phase out the premix subsidy through the Fisheries and Aquaculture Development Plan 2010-2015 (CRC, 2010), many believe that this will be postponed as premix has been given a special concession as a social product and, as a result, will not be affected by the policy.

\subsection{Mangroves}

Mangroves are critical for sustaining production in the coastal fisheries through their role as important nursery areas for fish species, including refuge from predators, high nutrient levels and shelter from physical disturbances (Manson et al., 2005). Some of these fish species are important to the coastal communities, as they provide a source of livelihood and food.

Protecting mangroves has also been identified as a potential 'triple win policy' (UNEP, 2012; Tompkins et al., 2012). Mangrove timber is used for cooking fuel and smoking fish, as well as for constructing houses. Trading in mangrove wood is another key livelihood source for many people, suggesting that there could be benefits for the poor by maintaining the integrity of the mangroves for sustainable harvesting. Mangroves also provide protection from erosion and storms that affect coastal communities, and can thus support adaptation. Finally, recent studies show the carbon sequestration potential of mangroves (King 2012).

In Ghana, there are six species of West-Central African mangroves that cover about 140 $\mathrm{km}^{2}$. They are limited to a very narrow, non-continuous coastal area around lagoons on the west of the country; and to the east, on the fringes of the lower reaches and delta of the Volta River (UNEP, 2007). In the Lower Volta, the total estimated value for mangrove related harvesting and contribution to marine fisheries is over US $\$ 6,000,000$ per year. This does not include other mangrove ecosystem services such as erosion control or trapping of pollutants (Gordon et al, 2009).

Ghana is a signatory to a number of mangrove-related international conventions, including the Convention on Climate Change, the Convention on Biodiversity, the Convention on International Trade on Endangered Species, the Convention on Ozone Layer and the Ramsar Convention on the Conservation of Wetlands. Various phases of the National Action Plans for effective implementation of these international conventions have included the protection of mangroves. However, despite these efforts, there are still inadequate policy, law and institutional provisions that have been made for mangrove forests. Between 1980 and 2006, the mangrove area in Ghana fell from $181 \mathrm{~km}^{2}$ to $137 \mathrm{~km}^{2}$, representing a loss of $24 \%$ (UNEP 2007).

The Wildlife Division of the Forestry Commission and other agencies such as the Lands Commission and the Department of Town and Country Planning are responsible for implementing national policies and programmes for the management of mangroves and associated wetlands. Other ministries and agencies who have activities that border on mangroves and biodiversity in general include Ministry of Environment, Science, Technology 
and Innovation, Lands and Forestry, Food and Agriculture, Environmental Protection Agency etc. At the regional level is the Regional Coordinating Council. However, it has been observed that despite the good structures in place, such first level institutions (central government, academic institutions, local government, donor agencies) are limited by logistical capacity and inadequate communication and information sharing to users. Poor attitudes towards mangrove and wetlands lead to its exclusion from development planning processes (Ajonina, 2011). At the local level, there are various interest groups including the District Assemblies with their substructures, civil society groups, producer groups and trade associations, traditional authorities, commercial organizations and local communities around the mangrove forests.

\subsection{National climate change policy}

With increasing evidence of the impacts of climate change on livelihoods and the well being of Ghanaians, the need to formulate climate change policies consistent with the Ghana poverty reduction strategy and national development plans culminated in the National Climate Change Policy (NCCP) (GoG, 2014). The NCCP, developed through extensive series of consultation workshops, recognises the contribution of the fisheries sector to livelihoods in Ghana. It is not highlighted as a sector on its own, but has been addressed under the first of the five priority areas:

1. Agriculture and Food Security (Priority Area 1)

2. Disaster preparedness and response

3. Natural resource management

4. Equitable social development (includes health, water \& sanitation, gender and migration)

5. Energy, industrial and infrastructural development.

The NCCP makes specific references to fisheries related issues in Priority Area 1, with a specific programme area to support adaptation in the fisheries through actions such as:

i) Building and strengthening the capacity of extension officers in climate-smart agriculture to enhance support to farmers and fishermen,

ii) Promoting capacity-building for farmers and fisherfolk and building awareness on climate change issues and

(iii) Designing and implementing programmes on fisheries management and disease control, which integrate climatic and hydrological parameters.

The protection of mangroves is included under Priority Area 3, with programme areas focusing on improved marine and coastal ecosystem management and ecosystem-based adaptation. Priority Area 5 focuses on programmes to mitigate GHGs through adoption of low emission and clean energy technology, as well as improving efficiency and the consumption and production of energy.

\subsection{Climate compatible development options}

The following section summarizes the discussions held with various stakeholders on their perspectives of contradictions and competitions between the various actors as described for each of the policies described in Section 5 and discusses their potential for CCD. 


\subsection{Case study 1: Fuel subsidies and the politics of premix}

Subsidies for fossil fuels have been identified globally as a source of carbon emissions that constitute an obstacle to transitions to low-carbon societies (Whitley 2013). In addition, IMF analysis also suggests that fossil fuel subsidies very rarely benefit the poor proportionally, and the majority of subsidy programmes directly benefit the richest $20 \%$ of society (Arze del Granado et al. 2010). As a result, there has been a growing consensus on the co-benefits of reforming subsidies for fossil fuel consumption. Support for this has come from a range of actors, including multinational institutions like the IMF (The Economist 2014), environmentalists concerned about climate change (Frecheville 2012) and some developing country governments concerned about the growing costs of subsidies. This growing movement worldwide in favour of reforming subsidies for fossil fuels is manifested in the declaration at the 2009 G20 summit in Pittsburgh, in which countries would aim to phase out such subsidies.

There are, however, major political obstacles to reforming subsidies. Many have been quickly reversed in response to protests and opposition, for example in Nigeria and Bolivia in 2011. The current ruling party in Ghana (the National Democratic Congress) promised to maintain the premix subsidy, and this is thought to have played a key role in their success during the 2008 presidential elections (Crawford, 2012; Finegold et al., 2010). The previous government had tried to get people to support subsidy reform. David Victor has argued that subsidies constitute 'a visible way to deliver benefits in exchange for political support', and therefore have a strong political logic to be retained (Victor, 2009).

In Ghana, there has been some progress in reforming a number of key fossil fuel subsidies by step-wise removal of subsidies or linking fossil fuel price to global oil prices. In the fisheries sector, some subsidies on fuel have been removed, such as the marine diesel, but not the premix fuel which artisanal fishermen use. While the global discussion of removal appears to make an attractive case for premix subsidy reform as a 'triple win' policy change, there is still substantial opposition in Ghana. The premix subsidy has been deliberately left off the agenda for two main reasons. Firstly, it is considered as a social product that benefits artisanal fishermen, a group that is regarded as poor and vulnerable. This argument was supported by a number of interviewees, particularly those within the fishing communities and their representatives. While there is a clear consensus that the current distribution of the fuel is not ideal, removing it altogether was identified as something that would make people considerably poorer in fishing communities. Reducing the premix subsidy from $90 \%$ to $50 \%$ result in 'increasing' prices that mean fishermen are able to buy less fuel and travel less to fish, resulting in reduced catch. Fishermen recently protested against the high costs of fishing, which has led to boats not being able to go to sea. They are requesting the government to review the subsidies (Daily Graphic, 27 March 2014). Fish traders, most of whom are women, also argued that this has affected them and consumers, as when catches are low the fishermen demand higher prices. Thus, there is a broader range of beneficiaries from the premix than the fishermen themselves.

Secondly, while subsidy removal is often proposed in the policy literature alongside 'compensation policies', this concept was not convincing to fishermen's groups, who felt that the Government commonly neglects or excludes them and that supply of subsidised premix is one policy that does benefit their livelihoods. From their point of view, even if subsidies are removed, the savings made should be passed on to the directly affected communities.

Therefore, given the context of generalised distrust and corruption in the sale and availability of premix, subsidies that appear to be 'inefficient' on paper can be the best possibility for 
vulnerable groups. ${ }^{6}$ Moreover, while it is easy to criticise a policy that gives incentives for fishing in spite of growing scarcity, the options for alternative livelihoods are limited. Informal job markets can get saturated easily, educated young people often find themselves unemployed, and even attempts at supporting land-based 'alternative livelihoods' can falter in the face of land scarcity. In this context, some participants at the Learning Event ${ }^{7}$ feared that removing the subsidy would actually lead people to move into illicit activities, or to compete with other poor people for livelihoods. This questioned some of the assumptions made in favour of subsidy reform.

Nevertheless, there is widespread agreement that current distribution of premix fuel is imperfect, because it is subject to party political biases which favour some fishermen over others. In some regions, it is not always fishermen who oversee the distribution as is stipulated by the law, but party functionaries. Thus, the policy creates opportunities for rentseeking at different stages of the supply chain. This has led to a feeling of scepticism towards the policy among some fishermen's representatives, who argue that the impact of party politics is detrimental to its impact. An implementation of premix distribution that avoids these distortions would, in theory, be far more equitable. However, politicians have powerful incentives to control it, with its inequitable and inefficient distribution, because they benefit in terms of votes and maintaining client networks. There have been some attempts to improve the distribution in recent years, as fishermen's organisations have appealed to the Government to tackle corruption. Some people have been suspended for malpractice. In addition, the Government has dyed the fuel in order to track it more effectively and prevent its use outside the fishing sector.

Majority of the stakeholders consulted in this study expressed a desire for the fuel subsidy to be administered more efficiently and fairly, rather than removing it. It is unclear at the moment whether it could ever be politically feasible to remove it and, perhaps more importantly, whether it could be equitable. As the fishery is an open access resource that needs to be properly managed, some stakeholders were concerned about any policies that support overfishing. They argued that there are potential adaptation benefits of not supporting an unsustainable activity through the premix subsidies, but by financing other more effective social policies targeting poor fishing communities. Another suggestion was to provide incentives for those who fish properly. Fishermen have other demands that could theoretically be conceded to 'compensate' for any loss of the fuel subsidy. These include greater support to purchase boats and motors. But the fishers generally hope these demands could be additional to the subsidy, rather than a substitute for it. Improving the distribution of the premix so that it is more efficient and more equitable may depend on forming new political coalitions, rather than removing politics altogether. The challenge would then be to identify those political actors who could have something to gain by making a firm and genuine commitment to distributing the fuel according to the guidelines. However, it is questionable whether such an improvement would necessarily constitute major 'triple win', as it would not necessarily bring about a significant effect on the mitigation of greenhouse gas emissions.

\subsection{Case study 2: Mangrove protection}

In Ghana, international commitments and strong traditional management systems have protected and regulated mangroves in some areas. But there is still increasing pressure by a

This reflects Victor's analysis of India, where an electricity subsidy is viewed by farmers as a key test to judge whether politicians respond to their interests (Victor 2009).

A one-day learning event on the political economy of climate compatible development was held on the $18^{\text {th }}$ February 2014 in Accra. Stakeholders from various institutions within Ghana discussed the linkages between climate change and the fisheries sector, mapped out the key actors in the fisheries sector, and identified strategies for overcoming factors affecting the sector. Attendees are listed in Annex 2. 
growing population for the conversion of mangrove areas into settlements, fields or salt pans. The timber is also used illicitly for building material, fuel, smoking fish etc (UNEP, 2007). The damming of the Volta River in 1964 reduced downstream water supply, which affected a large stretch of mangroves, both ecologically and through intensified exploitation by communities who had lost their traditional livelihoods in agriculture and fishing (Rubin et al, 1999).

Many interviewees felt that poverty is a major force driving mangrove destruction by coastal communities. This was especially the case for women, who trade mangrove wood in the absence of other livelihood options, and are highly dependent on mangrove for fuel and construction materials. Alternative cooking fuels, such as liquid gas, are too expensive for many, and even relatively wealthier people may prefer to save money by using wood. It is also felt that fish taste nicer and are better preserved when they are smoked with mangrove wood rather than with gas.

Protecting mangroves depends partly on understanding the land tenure arrangements in coastal areas. This is complex, as land tenure varies across different regions. In some areas, tribal chiefs own large tracts of land, but in others it is families or clans who are the landholders. This is in contrast to inland forests that have been included in plans for REDD+ in Ghana, which are owned by the Government and therefore appear to be simpler to protect. Due to a lack of clear land use policies, mangroves are often incorporated into community lands for use as firewood. Others consider that it is not so much the land tenure that is the key issue, but rather that mangroves are considered a free resource, and there are no incentives to protect them. One explanation for the lack of Government interest in mangroves is that, unlike with forestry, there are no possibilities for exporting timber.

One possibility is that through REDD+ or other instruments, communities and authorities could receive payments for the ecosystems services provided by mangroves. To date, REDD+ in Ghana has been considered in terms of its inland forests, but there are signs that this could change. The Coastal Sustainable Landscapes Project (CSLP), for example, is a Government of Ghana/USAID conservation project that is exploring mangrove potential for carbon sequestration in six coastal districts in the Western Region of Ghana. The Netherlands Development Organisation (SNV) has looked into the same possibility on the Volta coastline.

Another requirement for the protection of mangrove is proper classification, mapping and zonation of land use activities. Pollution and contamination caused by diverse actors, such as illegal mining activities or construction of salt pans are damaging to mangroves. A concern is the impact of the oil and gas industry, especially on the mangroves in the Amazuri wetlands in the Western Region. Mangroves within Ramsar sites are supposed to be under protection but only from activities within its boundaries. Activities beyond the boundaries can only be addressed by a national legal instrument such as the EPA. Although development plans have to be approved by the EPA, the general view of stakeholders is that enforcement is weak, and that it may be possible to pay off officials with bribes.

With increasing coastal developments, the support of green tourism and eco-hotels in areas near mangroves instead of standard resort developments might also contribute to mangrove protection; potentially including a national eco-tourism accreditation. Crucially, any new policy reform must appeal to the needs of stakeholders in livelihoods, fisheries, forestry, industry and agriculture, who could potentially have a role in mangrove protection.

The role of poverty and inadequate alternatives in driving mangrove destruction might also require consideration of alternative livelihoods. For example, destruction of mangroves for fuelwood could be limited by promoting fuel efficient cook stoves, as some NGOs have 
already been piloting, or even by subsidising gas for cooking as an alternative fuel. Another possibility is to focus specifically on 'biodiversity hotspots' to protect them, thereby concentrating resources in key areas. Some actors, particularly NGOs, also advocate greater efforts to educate coastal people about the importance of mangroves in supporting livelihoods. In turn, local people could then pressurise authorities to protect resources more effectively.

While there are a number of different approaches to supporting mangrove protection, they all depend on having institutions that have strong incentives and ability to implement policies. There are major institutional barriers to effective mangrove protection in Ghana. In the late 1980 s and 1990s, there was significant progress in mangrove protection, with the cooperation of some key donors. However, when donors pulled out and governments changed, mangrove protection dropped off the political agenda, and degradation has since increased significantly. The agency that is supposed to be in charge of protection, the Wildlife Commission, is under-resourced. In many cases, agencies move into activities beyond their remit in order to access finance. This has the effect of causing overlaps and conflict between different institutions. Moreover, mangroves do not have their own ministry, sub-ministry or agency and thus are easily left out of environmental protection efforts. One view is that mangroves would need their own institution specifically dedicated to protecting them. Another suggestion is the replication of approaches used successfully by traditional authorities in some areas to ensure sustainable exploitation of the mangroves. Regardless of the approach taken, it is clear that mangrove protection depends heavily on incentivising and empowering key government institutions as well as the appropriate traditional authorities.

\subsection{Reflections on the political economy of climate compatible development}

The political economy framework is focused on three types of processes:

a. The policy and actor context underpinning CCD in this sector

b. The power relations, competition, cooperation and conflict between different interest groups driving policies and access to resources

c. The distributional consequences of different actions on these interest groups, and possible trade-offs between groups and different objectives.

One of the key aspects is to what extent it is possible to implement policy in the context of wider power relations. What is the relative ability for existing fisheries policies to operate successfully? Can a CCD approach emerge from that? In other words, we need to understand the context of political economy factors that constrain or support policy, how much control relevant actors have over these and what is the potential for successful CCD to emerge.

There are two key contextual problems that constrain actors and affect the ability to implement policy. The first is that Ghana's artisanal fisheries are unable to supply enough to meet demand and to match prices of imported fish. The second is that given the livelihood options and low income levels of artisan fishers and the livelihoods of those dependent on the processing and trading of coastal-caught fish, hundreds of thousands of mostly poor people are locked into a process that gives them perverse incentives to fish (with many of them using subsidised fuel) when stocks are collapsing and unsustainable. The two are clearly intertwined. 
Because of declining stocks (and lower prices of imported fish), Ghana is now importing half of the fish consumed by its people. The Minister of Fisheries and Aquaculture attributed this to poor governance, open access fisheries, and illegal fishing..$^{8}$ In fact, this is only a partial explanation. Another factor is that imported fish is cheaper. The Minister is also reported to blame imports for undermining Ghana's fisheries, and that it will support an expansion of fish farming in the country. ${ }^{9}$ Imports, especially of farmed tilapia from China, Taiwan and other Southeast Asian countries are very significant and popular, even though tilapia is not a native fish. Hence, defending the livelihoods of the hundreds of thousands of inshore artisan fishers and those who depend on fish processing and trading requires dealing with the impossible. Support for artisan fisheries in the current context will perpetuate overfishing, in a context where landed fish prices cannot anyway compete with imports.

Another problem for Ghanaian policy and actors is that while much is said about illegal fishing (which undoubtedly happens with the artisan fleet), the effect of this on stocks has to be measured in relation to far larger take from deep water industrial fishing. Trawlers from foreign countries are very active in West African waters (Vidal 2012). Ghana can try to reduce their impact within Ghana's territorial waters, especially when it is illegal. But it cannot control overfishing off all West Africa, where illegal fishing outside its waters affects stocks that eventually would be in Ghana's waters. A recent investigation of Spain's fishing industry showed that it has been severely indicted for illegal activities, with some companies continuing to receive European Union subsidies after they had been found guilty of illegal fishing. Spain is the largest recipient of government and EU subsidies, with total receipts of $\$ 8$ billion from 2000 to 2012 (IClJ 2012). By contrast, the Spanish aid to Ghana for a freezer plant that opened in 2013 was worth Euro 1 million. ${ }^{10}$

While institutionalised mal-adaptive European subsidies and illegal fishing by European and other foreign trawlers continues, Ghana is ironically facing sanctions from the EU for its failure to control illegal fishing by its own fleet. A report from June 2014 says that the European Commission (EC) 'has warned that henceforth any incident of illegal, unreported and unregulated (IUU) fishing by a Ghana-flagged vessel will result in a total ban on fish products exported from Ghana to EU markets.' ${ }^{11}$ As a result, the Ministry of Fisheries and Aquaculture Development (MoFAD) has threatened to impose penalties on any local vessel found to be engaged in IUU fishing. This dispute has actually been going on for several years, with EU getting increasingly threatening to Ghana, while failing to act on its own fleet's illegalities (Copeland 2014). There is also significant irony in the fact that pursuing Ghana for emissions from its poor fishers' use of premix pales into insignificance against the subsidies (reputed to be $\$ 27$ billion a year) used by rich countries to support their fishing fleets, some of which are used to subsidise fuel costs (Kende-Robb, 2014).

Within Ghana, the disputes about premix and the goal of reducing the subsidy are the source of significant political conflict, as the relevant actors try to maintain their contradictory positions. Artisan fishers want the subsidy to be retained, arguing that they cannot afford to put to sea after the 2013 reduction in subsidy. In March 2014, an investigation by the Daily Graphic newspaper found more than 500 boats were beached, when normally they would be out at sea. This affected more than 30,000 people in the fishing to retailing livelihoods. The Inshore Fishermen Association was appealing to the government to restore the full rate of the subsidy. ${ }^{12}$ The government was itself facing a significant financial deficit, and argued that the higher rate of tax it now charges on premix would help to reduce it (the subsidy was actually implemented through the tax rate being lower). It also argues that so much fuel is diverted

\footnotetext{
$8 \quad$ www.ghanaweb.com/GhanaHomePage/business/artikel.php?!D=297409

$9 \quad$ www.thefishsite.com/fishnews/22674/tilapia-imports-threaten-ghanas-fisheries-sector

10 www.thefishsite.com/fishnews/21967/ghana-opens-1m-spanishfunded-fish-cold-store

11 www.thefishsite.com/fishnews/23354/illegal-fishing-could-see-eu-ban-fish-imports-from-ghana

12 http://graphic.com.gh/news/general-news/20240-fishermen-ground-canoes.html
} 
from its main target group that the intention of the subsidy is significantly damaged. There is certainly an incentive for corrupt redirection of premix. After further price rises in April 2014, premix is still less than half the price of premium petrol.

There is no evidence that there is any intention to reduce GHG emissions in this change of policy on fuel subsidies. Thus, if premix continues to be sold at the higher price, any emissions reduction is a side product. While from a climate change context, any reduction might be welcomed. There would need to be a full audit to ensure that any fisher people and others diverted away from fishing, processing and selling do not have to engage in alternative livelihoods that have greater emissions or other harmful impacts (e.g. deforestation).

This also shows how the livelihoods can be interrelated. The second case study shows how other demands and priorities for many years have damaged the coastal and delta mangroves. The factors range from ecosystem disruption of the Volta river delta because of the Akosombo dam, local people's need for fuel wood (including for fish smoking), timber for construction, coastal settlements and tourist resorts. There is a serious need to bring mangroves into more sustainable use (both to support livelihoods that will continue to use the wood anyway and to provide coastal protection from possible climate change impacts). The key potentially beneficial linkage to fisheries is through the spawning and regeneration of stocks in protected mangroves. As in most situations, the policy implementation constraints for mangrove protection derive mainly from the lack of incentives for many people who use the wood to change their behaviour. Actors related to coastal fisheries do not see the need to protect mangroves, despite their significant function in spawning and protecting young fish.

Despite government acknowledgement in the NCCP of the link with climate change, there is little prospect of a significant change from the current situation in which existing protection policies have not prevented a significant decline in mangrove forest discussed above. There are current mangrove restoration efforts, but these are limited because there are many discontinuous and small patches. Many are carried out by NGOs, but there remains the problem that most of the areas are considered common property resources with little protection through ownership. The Forestry Commission has not made significant steps yet in relation to mangrove under its own remit, as historically they have not been included in the legal definition of forests, and do not yield timber in the same way that inland forests produce an incentive for management and extraction. There is some recent hope that attitudes may change in some government actors because of the scope for carbon credits. IUCN staff considers that there needs to be protection through biodiversity hot spots. Ramsar wetland mangrove sites appear to be protected reasonably well, and so this might be possible. The recent Forest and Wildlife Policy under the Ministry of Lands and Natural Resources (MoLNR, 2012) has declared the sustainable management of mangroves as one of its Strategic Directions.

In relation to both case studies, a further key context is the government's priority given to development, and whether pursuit of this will take priority over the needs of dealing with climate change. This policy context is potentially contradictory, because despite its formulating the National Climate Change Policy (NCCP), and having the existing National Climate Change Adaptation Strategy (NCCAS), the recent rapid development of the oil and gas industry does not seem to be regarded as problem. The country is significantly energydeficient, and, at the moment, has a major contribution from its renewable energy sources in hydro-electric power. But burning fossil fuels (and gaining revenue from its exports) is being traded against the benefits of economic growth. The distributional aspects of this would need to be fully accounted for in order to justify this as a development gain. 
What we can see from the context, competition and consequences of the way that premix and mangrove issues play out in relation to CCD is the high degree of complexity, the remoteness of these issues from any type of climate change agenda, and an inadequate recognition of the interconnections between mangroves and fisheries, mangroves and benefits for climate change, subsidised premix as a maladaptation for both climate mitigation and fisheries protection, and poverty reduction for fisher and related livelihoods being seen as a political rather than an equity issue that can lead to beneficial policies that can lead to CCD.

The two cases illuminate some of the challenges to CCD, and require a reflection about the feasibility of CCD, and the way to achieve it. For both, the premix subsidy and mangrove protection, the interviews and discussion at the learning forum indicate general agreement that any significant progress must be made through significant institutional change rather than new policies per se. In many cases, the appropriate guidelines to ensure that policy objectives are met are already in place, but there is a need for greater understanding about why they are not implemented according to formal rules. One danger of CCD is that it will simply add on an additional set of objectives and a new discourse to mobilise projects without altering the pre-existing institutional failures that characterise policymaking in a number of developing countries.

The research also highlighted the need to see CCD more as a dynamic process, whereby the space available for triple wins may be increased over time (Figure 4). This would require understanding precisely what forces are keeping the circles apart, preventing synergies from happening.

\section{Figure 4 Expanding the potential for 'triple wins'}

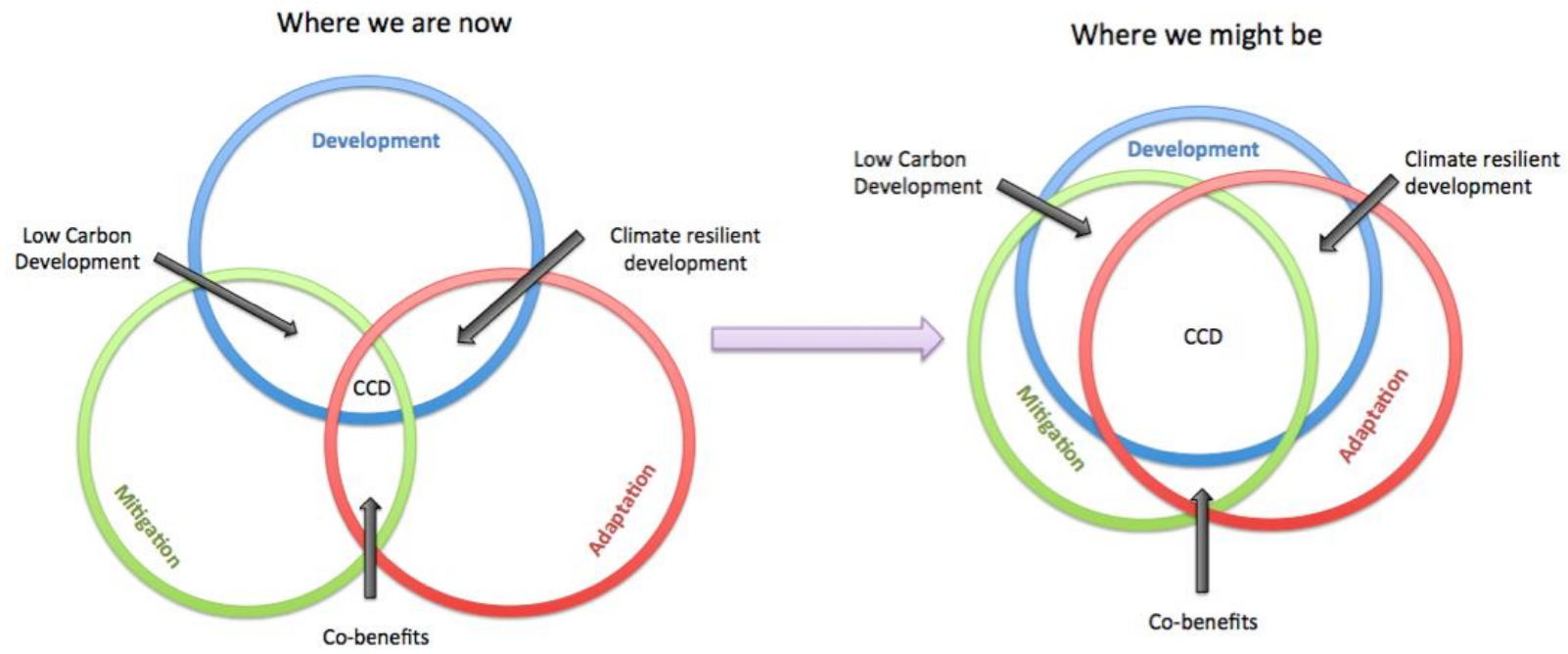

Source: authors' own.

At the same time, these three circles are dynamic across time and space, and at different moments, particular circles will be more or less interconnected (Figure 5). This was clearly the case with Ghana's own climate change strategies, which have shifted as a result of different actors' interventions.

However, even this more dynamic conception of CCD still makes an assumption that responding to climate change entails considering multiple objectives that can have mutual benefits in the same policies. This is difficult, because poverty reduction policies require a 
focus on the poor, who are generally responsible for low amounts of emissions. It was clear from the interviews and the learning event that the majority of actors in Ghana prioritise 'development' above adaptation to climate change; and mitigation is only considered attractive in cases where it could be achieved as a by-product, rather than as part of an explicit policy to drive towards low-carbon development.

In the case of the development of Ghana's climate change strategy, the drive towards low carbon development was largely the result of external actors and priorities, and subsequent consultations with stakeholders resulted in the de-emphasising of mitigation objectives in favour of development. Furthermore, one of the policy reforms that could potentially be framed as attaining 'triple wins', namely removal of the premix subsidy, was explicitly rejected by key stakeholders as being an anti-poor and inequitable proposal. There was also general agreement that people in coastal communities prioritise visible project interventions that respond to current development problems rather than long-term considerations. Therefore, it is necessary to acknowledge that if politicians appear to be 'short termist', this is often because they are responding to 'bottom-up' pressure to deliver results.

This raises questions about whether the attempts to achieve 'triple wins' is feasible, or whether it could ultimately result in a backlash against the notion of low carbon development. It may be possible, for example, that the most significant moves that countries could take towards low carbon development are to be found in the industrial and energy sectors where any changes are unlikely to have direct and feasible co-benefits for poor people. At the same time, requiring policies for the poor to achieve triple wins could lead to a dilution of their own effectiveness in reducing poverty. At best, CCD might do better to aim for successful development interventions that also deliver co-benefits for adaptation and mitigation rather than trying to hit the 'sweet spot' in the middle, right from the start.

\section{Figure 5 Dynamic triple wins across space and time}
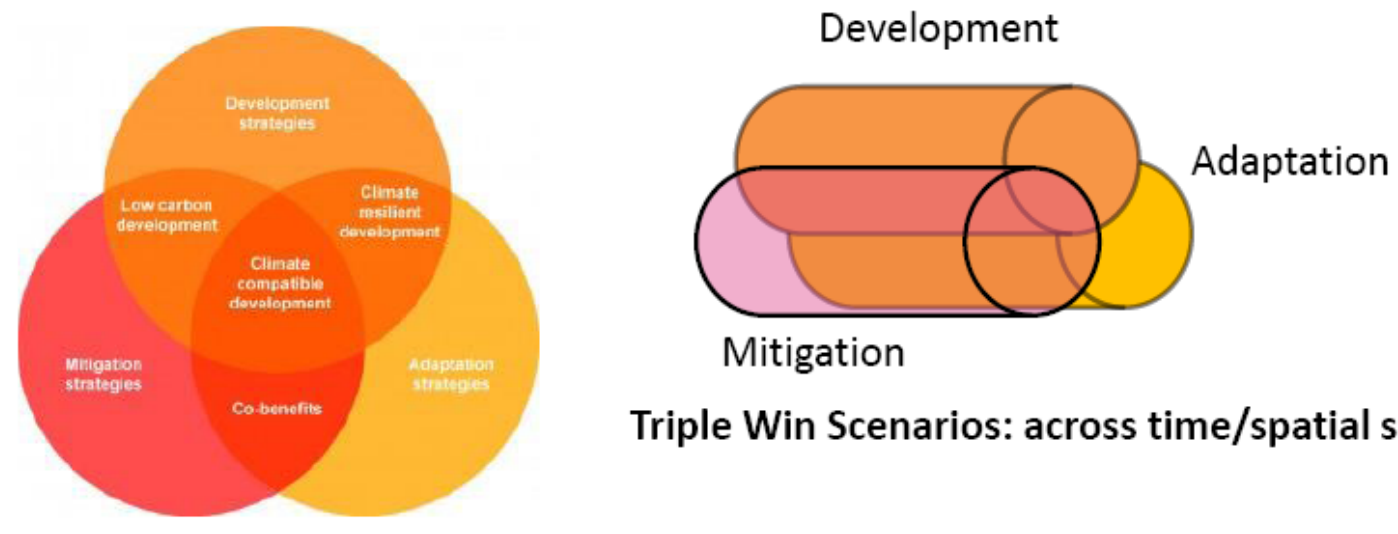

Triple Win Scenarios: across time/spatial scales
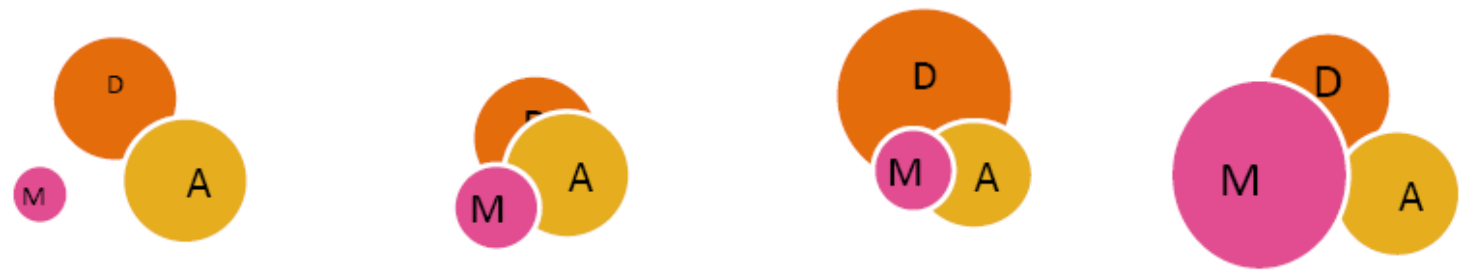

Timeline: (Life of Decision Making Unit/Funding Cycle/Election Period) 


\section{Annex 1 List of interviewees}

\begin{tabular}{|c|c|}
\hline Institution & Name \\
\hline Accra Metropolitan Assembly & Mr. Nii Armah Tagoe \\
\hline Department of Marine and Fisheries Sciences, University of Ghana & Dr. Francis Nunoo \\
\hline Environmental Protection Agency & Carl Fiati \\
\hline Environmental Protection Agency & Dan Benefoh \\
\hline Fisheries Alliance & Mr. Richster Nii Amarfio \\
\hline Fisheries Commission & $\begin{array}{l}\text { Mr. Samuel Quaatey } \\
\text { Mrs. Doris Yeboah }\end{array}$ \\
\hline Forestry Commission & Mr. Robert Bamfo \\
\hline Ghana National Canoe Fishermen Association & Mr. Nii Abiokyere Kwanda \\
\hline Ghana Navy & Commander Eric Abrahams \\
\hline Hatof & Mr. Samuel Dotse \\
\hline International Union for Conservation of Nature & $\begin{array}{l}\text { Dr. Adeleke Adewale; } \\
\text { Mr. Samuel Kofi Nyame; } \\
\text { Ms. Saadia Bobtoya }\end{array}$ \\
\hline Institute for Environment and Sanitation Studies & Prof. Chris Gordon \\
\hline Keta Municipality & Eco-lodge owner, Dougal from Bath \\
\hline Keta Municipality & Francis, Facilitator \\
\hline Keta Municipality & Chief fisherman, Defoe Pilo \\
\hline Keta Municipality & Mr Viteshi \\
\hline Keta Municipality & Female fishmonger \\
\hline Keta Municipality & John Lomo (Assembly member) \\
\hline Keta Municipality & Fishermen on beach \\
\hline Keta Municipality & Female fish trader \\
\hline Keta Municipality & Wildlife Commission man \\
\hline Ministry of Fisheries - Marine Fisheries Monitoring Division & Mr. Joseph Yeboah \\
\hline Ministry of Fisheries - Marine Fisheries Research Division & Mr. Emmanuel Dovlo \\
\hline National Development and Planning Commission (NDPC) & Mr. Winfred Nelson \\
\hline National Petroleum Authority & Mr. Rashid Abass \\
\hline Forestry Commission & Mr. Robert Bamfo \\
\hline Regional Institute of Population Studies (RIPS), University of Ghana & Dr. Delali Dovie \\
\hline Water Research Institute, CSIR & $\begin{array}{l}\text { Dr. Ruby Asmah } \\
\text { Dr. Maama Entsua-Mensah }\end{array}$ \\
\hline Wildlife Division (Forestry Commission) & Mr. Charles C. Amankwah \\
\hline
\end{tabular}




\section{Annex 2 List of participants at learning event}

\begin{tabular}{|c|c|}
\hline NAME & INSTITUTION \\
\hline Adam A. Rashid & Ghana Petroleum Authority \\
\hline Adelina Mensah & IESS \\
\hline Ama Kudom- Agyeman & P.A. Communications \\
\hline Capt (GW) E. A. Kwafo & F.E.U. National Coordinator \\
\hline Christian Nii Aponsah & Ministry of Fisheries and Aquaculture Development \\
\hline Daniel Benefor & EPA \\
\hline Dr. Adewale Adeleke & IUCN \\
\hline Dr. F. K. E. Nunoo & Dept. of Marine and Fisheries Science, U.G. \\
\hline Elaine Mercer & IDS \\
\hline Elaine T. Lawson & Institute for Environment and Sanitation Studies \\
\hline Emmanuel K. Dovlo & Marine Fisheries Research \\
\hline Eric Abrahams & Ghana Navy \\
\hline Eunice Ofoh Anum & Fisheries Commission \\
\hline FLT/LT M. Tackey (RTD) & NAFAG \\
\hline Francis Avura & CARE International \\
\hline Franklin A. Annan & GA Mashie Development Agency (GAMADA) \\
\hline Fuseina Issah & Ministry of Fisheries and Aquaculture Development \\
\hline Jon Phillips & Kings College London \\
\hline Ken Kinney & The Development Institute (ID) \\
\hline Laar Baman & Marine Police \\
\hline Nana Jojo Solomon & Ghana National Canoe Fishermen \\
\hline Nii Okai Okaishie III & Ghana National Canoe Council \\
\hline Noble Wadzah & Oilwatch/ FOE Ghana \\
\hline Prof. Chris Gordon & IESS \\
\hline S. N. A. Codjoe & Regional Institute of Population Studies (RIPS) \\
\hline Saadia Bobtoya & IUCN \\
\hline Samuel Dotse & HATOF/CCATCD/RIPS \\
\hline Samuel Kofi Nyame & IUCN \\
\hline Stephen Kankam & Hen Mpoano (Our Coast) \\
\hline Stephen Kankam & Hen Mpoano \\
\hline Thomas Tanner & Institute of Development Studies (IDS) \\
\hline Winfred Nelson & National Development Planning Commission \\
\hline
\end{tabular}




\section{References}

Abane, H.; Akonor, E.; Ekumah, E. and Adjei, J. (2013) Four Governance Case Studies and their Implications for Ghana Fisheries Sector, USAID-URI Integrated Coastal and Fisheries Governance (ICFG) Initiative, Narragansett RI: Coastal Resources Center, Graduate School of Oceanography, University of Rhode Island

Agrer (2011) Final Technical Report: Formulation of Implementing Text of the Draft Fisheries Legislation in Benin and Up-dating of the Marine Fisheries Master Plan in Ghana,

ACPFish II Project ref. CU/PE1/SN/10/001. Available online: http://acpfish2eu.org/uploads/projects/id14/Final\%20Technical\%20Report\%20\%20ACP\%20Ghana\%20-\%2030\%20-05-11.pdf

Ajonina, G. (2011) Rapid Assessment of Mangrove Status to Assess Potential for Payment for Ecosystem Services in Amanzule in the Western Region of Ghana, USAID Integrated Coastal and Fisheries Governance Program for the Western Region of Ghana, Narragansett RI: Coastal Resources Center, Graduate School of Oceanography, University of Rhode Island

Allison E. and Ellis F. (2001) 'The Livelihoods Approach and Management of Small-scale Fisheries', Marine Policy 25: 377-88

Allison, E.H.; Adger, W.N.; Badjeck, M-C.; Brown, K.; Conway, D.; Dulvy, N.K.; Halls, A.; Perry, A. and Reynolds, J.D. (2005) Effects of Climate Change on the Sustainability of Capture and Enhancement Fisheries Important to the Poor: Analysis of the Vulnerability and Adaptability of Fisherfolk Living in Poverty, Project No. R4778J. Final Technical Report, Fisheries Management Science Programme, MRAG/DFID, London, $164 \mathrm{pp}$

Arze del Granado, J.; Coady, D. and Gillingham, R. (2010) The Unequal Benefits of Fuel Subsidies: A Review of Evidence for Developing Countries, Washington DC: IMF

Barange, M. and Perry, R.I. (2009) 'Physical and Ecological Impacts of Climate Change Relevant to Marine and Inland Capture Fisheries and Aquaculture', in K. Cochrane, C. De Young, D. Soto and T. Bahri (eds), Climate Change Implications for Fisheries and Aquaculture: Overview of Current Scientific Knowledge, FAO Fisheries and AquacultureTechnical Paper 530, Rome: FAO: 7-106

Bennett, E. (2002) 'The Challenges of Managing Small Scale Fisheries in West Africa. Analytical Appendix 2', in Cemare, Management of Conflict in Tropical Fisheries, Final Technical Report, Portsmouth: University of Portsmouth

Cheung, W.W.L.; Lam, V.W.Y.; Sarmiento, J.L.; Kearney, K.; Watson,R.; Zeller, D. and Pauly, D. (2010) 'Large-scale Redistribution of Maximum Fisheries Catch Potential in the Global Ocean under Climate Change', Global Change Biology 16: 24-35

Copeland, D. (2014) 'West Africa has Vast Marine Wealth but it is Being Depleted by the World's Highest Levels of Illegal Fishing', The World Today 70.1, Chatham House, Available online: www.chathamhouse.org/sites/files/chathamhouse/public/ The\%20World\%20Today/2014/FebMarch/WT0114Copeland.pdf

Crawford, G. (2012) Ghana's Fossil-Fuel Subsidy Reform, Case Study 09, The Learning Hub, Brighton: IDS 
CRC (2013) Solving the Fisheries Crisis in Ghana: A Fresh Approach to Collaborative Fisheries Management, USAID-URI Integrated Coastal and Fisheries Governance (ICFG) Initiative. Coastal Resources Center, Graduate School of Oceanography, University of Rhode Island. 20p

CRC (2010) Hen Mpoano Our Coast, Our Future Western Region of Ghana, Coastal Resources Center, Ghana

Daily Graphic (2014) 'Fishermen Ground Canoes Due to Cost of Premix Fuel', 27 March. Available online: www.ghanaweb.com/GhanaHomePage/NewsArchive/ artikel.php?ID=304457

Dontwi J.; Dontwi, I.K. and Buabeng, S.N. (2008) 'Climate Change Impacts on Fisheries Production', in Agyeman Bonsu et al., Ghana Climate Change Impacts, Vulnerability and Adaptation Assessments, Ghana: Environmental Protection Agency: 14-55

Ellis, K.; Cambray, A. and Lemma, A. (2013) Drivers and Challenges for Climate Compatible Development, CDKN Working Paper, London: Climate and Development Knowledge Network

FAO (2010) Report of the FAO FishCode-STF/CECAF/FCWC Subregional Workshop on the Improvement of Fishery Information and Data Collection Systems in the West Central Gulf of Guinea Region. Accra, Ghana, 26-28 June 2007. Available online: www.fao.org/docrep/012/k7479b/k7479b00.pdf

Finegold, C.; Gordon, A.; Mills, D.; Curtis, L. and Pulis, A. (2010) Western Region Fisheries Sector Review. USAID Integrated Coastal and Fisheries Governance Initiative for the Western Region. Available online: www.crc.uri.edu/download/GH2009IFISH001_5081.pdf

Frecheville, N. (2013) Why We Hate Fossil Fuel Subsidies, WWF Blog. Available online: http://blogs.wwf.org.uk/blog/business-government/green-economy/why-we-hate-fossilfuel-subsidies-and-how-you-can-help-end-them/

Ghana Statistical Service (2014) Gross Domestic Product 2014, National Accounts Statistics. Available online: www.statsghana.gov.gh/docfiles/GDP/GDP_2014.pdf

Gordon, C.; Tweneboah, E.; Mensah, A.M. and Ayivor, J.S. (2009) 'The Application of the Ecosystem Approach to Mangrove Management: Lessons for Ghana', Nature and Faune 24: 30-41

Government of Ghana (2014) National Climate Change Policy, Accra: Ministry of Environments, Science and Technology

ICIJ (2012) Looting the Seas, International Consortium of Investigative Journalists. Available online: www.icij.org/projects/looting-the-seas-ii

IEA (2011) World Energy Outlook 2011, Paris: OECD Publishing

Katikiro, R.E. and Macusi, E.D. (2012) 'Climate Change on West African Fisheries and its Implications on Food Production', Journal of Environmental Science and Management 15.2: 83-95 
Kende-Robb, C. (2014) 'Why Illegal Fishing off Africa's Coast Must be Stopped', The Guardian, 19 June. Available online: http://www.theguardian.com/global-

development/poverty-matters/2014/jun/19/why-illegal-fishing-africa-must-be-stopped

King, L. (2012) Including Mangrove Forests in REDD Plus, briefing prepared for the Climate and Development Knowledge Network, LTS International. Available online:

http://lsi.co.uk/images/documents/including\%20mangroves\%20in\%20redd\%2B\%20lesl ey\%20king\%20lts\%20international.pdf

Koranteng, K.A. (2002) 'Status of Demersal Fishery Resources on the Inner Continental Shelf off Ghana', in J.M. McGlade, P. Cury, K.A. Korentang and N.J. HardmanMountford (eds), The Gulf of Guinea Large Marine Ecosystem, Amsterdam: Elsevier Science: $261-74$

Koranteng, K.A. and Mcglade, J.M. (2001) 'Climatic Trends in Continental Shelf Waters off Ghana and in the Gulf of Guinea, 1963-1992', Oceanologica Acta 24: 187-98

Lam, V.W.Y.; Cheung, W.W.L.; Swartz, W. and Sumaila, U.R. (2012) 'Climate Change Impacts on Fisheries in West Africa: Implications for Economic, Food and Nutritional Security', African Journal of Marine Science 34.1: 103-117

Lehodey, P.; Alheit, J.; Barange, M.; Baumgartner, T.; Beaugrand, K.; Drinkwater, K.; Fromentin, J.-M.; Hare, S.R.; Ottersen and Perry, G. (2006) 'Climate Variability, Fish and Fisheries', Journal of Climate 19: 5009-5030

Manson, F.J.; Loneragan, N.R.; Skilleter, G. and Phinn, S.R. (2005) 'An Evaluation of the Evidence for Linkages between Mangroves and Fisheries: A Synthesis of the Literature and Identification of Research Directions', Oceanography and Marine Biology: An Annual Review 43: 485-515

Ministry of Environment, Science and Technology (MEST) (2011) Ghana's Second National Communication to the UNFCCC

Ministry of Food and Agriculture (MoFA) (2002) Fisheries Act 2002, Act 625

Ministry of Lands and Natural Resources (MoLNR) (2012) Ghana Forest and Wildlife Policy. Available online: www.clientearth.org/external-resources/ghana/forests-andwildlife/2012-Forest-and-wildlife-policy-GHANA.pdf

Mitchell, T. and Maxwell, S. (2010) Defining Climate Compatible Development, CDKN Policy Brief, London: Climate and Development Knowledge Network

Mohan, G. (1996) 'Adjustment and Decentralization in Ghana: A Case of Diminished Sovereignty', Political Geography 15.1: 75-94

Mutimukuru-Maravanyika, T.; Asare, C.; Ameyaw, G.; Mills, D. and Agbogah, K. (2013) Ghana Coastal Fisheries Governance Dialogue: Developing Options for a Legal Framework for Fisheries Co- management in Ghana. USAID, Coastal Resources Center of University of Rhode Island and WorldFish Center

Nunoo, F.K.E.; Boateng J.O.; Ahulu A.M.; Agyekum K.A. and Sumaila U.R. (2009) 'When Trash Fsh is Treasure: The Case of Ghana in West Africa', Fisheries Resource 96: 167-72 
Perry, R.I. and Sumaila, R.U. (2007) 'Marine Ecosystem Variability and Human Community Responses: The Example of Ghana, West Africa', Marine Policy 31: 125-34

Rubin, J.A.; Gordon, C. and Amatekpor, J.K. (1999) 'Causes and Consequences of Mangrove Deforestation in the Volta Estuary, Ghana: Some Recommendations for Ecosystem Rehabilitation', Marine Pollution Bulletin 37.8-12: 441-9

The Economist, (2014) 'The Green-growth Twofer'. Available online: www.economist.com/blogs/freeexchange/2014/01/fossil-fuel-subsidies

Tanner, T.M. and Allouche, J. (2011) 'Towards a New Political Economy of Climate Change, IDS Bulletin 43.3: 1-14

Tompkins, E.L.; Mensah, A.; King, L.; Long, T.K.; Lawson, E.T.; Hutton, C.; Hoang, V.A.; Gordon, C.; Fish, M.; Dyer, J. and Bood, N. (2013) An Investigation of the Evidence of Benefits from Climate Compatible Development, Sustainability Research Institute 44, Centre for Climate Change Economics and Policy Working Paper 124, SRI Papers, Available online: www.see.leeds.ac.uk/fileadmin/Documents/research/sri/ workingpapers/SRIPs-44.pdf

UNEP (2012) Making the Case for Ecosystem Based Adaptation, Available online: www.seachangecop.org/sites/default/files/documents/2012\%2011\%20UNEP\%20\%20Making\%20the\%20Case\%20for\%20Ecosystem-based\%20Adaptation.pdf

UNEP (2007) Mangroves of Western and Central Africa. UNEP-Regional Seas Programme/UNEPWCMC. 92pp

Victor, D. (2009) The Politics of Fossil Fuel Subsidies Global Subsidies Initiative, IISD, Available online: www.globalsubsidies.org/files/assets/politics_ffs.pdf

Vidal, J. (2012) 'Is the EU Taking its Over-fishing Habits to West African Waters?', The Guardian, 2 April. Available online: www.theguardian.com/environment/2012/apr/02/ eu-fishing-west-africa-mauritania

Whitley, S. (2013) Time to Change the Game: Fossil Fuel Subsidies and the Climate, ODI. Available online: www.odi.org.uk/sites/odi.org.uk/files/odi-assets/publications-opinionfiles/8668.pdf

Wiafe, G.; Yaqub, H.B.; Mensah, M.A. and Frid, C.L.J. (2008) 'Impact of Climate Change on Long-term Zooplankton Biomass in the Upwelling Region of the Gulf of Guinea', ICES Journal of Marine Science 65: 318-24

Yamoah, K.K. (2012) Identification of Effective Strategies for the Enforcement of the Fisheries Regulation 2010 (L.I. 1968). Report prepared for Ghana National Canoe Fishermen's Council (GNCFC) -Western Region 